the unexplored depths of the fissure is a matter of pure conjecture. Whether a repetition of the finds in the fissure at Ray Gill, and in the lower cave earth of the Victoria Cave, with the addition of Palæolithic man, must be left for future exploration to determine.

Your Cominittee request reappointment, and that a grant of $£ 25$ be made to assist in the further exploration of the cave.

\title{
COREFSPONDEINCE.
}

\section{NOTES ON CONISTON FLAGS.}

Sir,-May I be allowed to point out that in my "Note on the Coniston Flags" in your last issue, the printer makes it appear that in microscopic work I made use of sections rather larger than are usually employed. Speaking of the garnets (p. 460), he makes me say that this mineral appears and disappears "within a few yards along the slide and a few feet across it."

Messrs. Voigt and Hochgesang, who make my sections for me, have very great skill in our work, but I do not think they could quite make slides of the size bere indicated! What I wrote was strike, where the printer has put slide. W. Maynard Hutohings.

NewCastle-on-Tyne, Oct. 7, 1891.

\section{CONCRETIONS IN MAGNESIAN LIMESTONE.}

Srr,-Has not Mr. Garwood omitted to consider a third possible method of origin for these and similar concretions? Infiltration and Segregation are not the only ways in which concretions are formed. Why should not the carbonate of lime have been obtained frow the water above, while that particular bed was being deposited? It is not necessary to suppose that the carbonate of lime must have been deposited in the bed and then segregated; it is surely more likely that it was in solution in the water above, and was precipitated by chemical action. The ammonia or ammoniacal compounds evolved from decaying organic matter might be the initial cause.

\section{A. J. Jukies Browne.}

\section{OBITUARY.}

WITH deep regret we record the following deaths:-

Charles Smith Wilkinson, F.G.S., F.L.S., V.P.L.S., N.S.W., the Government Geologist for New South Wales, who died at Sydney on 23rd August, 1891, aged 47 years.

Philip Herbert Carpenter, D.Sc. (Camb.), F.R.S., F L.S., Science-Master of Eton College, who died on 21 st October, 1891, aged 39 years.

We hope to publish a fuller notice of these eminent geologists and palæontologists next month. 